\section{Radar Quantitative Precipitation Estimation improvement in Champagne vineyard.}

\section{Basile PAUTHIER ${ }^{1}$, Sébastien DEBUISSON ${ }^{1}$, Arnaud DESCOTES ${ }^{1}$, Julien PERGAUD², Sylvain MAILLARD ${ }^{1}$}

\author{
1 Comité Champagne, 17 rue Chandon Moët \\ 51200 Epernay,France.basile.pauthier@civc.fr \\ 2 Airmet Conception, 151 rue d'Auxonne 21000 \\ Dijon, France
}

\begin{abstract}
Rainfall has a crucial importance in viticulture, especially in Champagne vineyards, where irrigation is prohibited. Rainfall directly influences the phytosanitary pressure, nitrogen mineralization, flowering conditions, parcel practicability, soil erosion etc... In these conditions, implementing a weather stations network is the solution that the Comite Champagne chose to monitor rainfall all over the Champagne appellation since the 1990's. This networks is actually composed of 42 weather stations implemented in order to have the best spatial coverage as possible. The Comité Champagne also obtain some weather stations data from Météo France, the French national weather service. Even with that network, capturing all rainfall events accurately is difficult, especially in convective cases. Therefore, the interest in radar data has increased, to capture rainfall everywhere. Some tests have been previously made with PANTHERE radar data from Météo France with a resolution of $1 \mathrm{~km}^{2}$, results were promising, but presented inaccuracies particularly in convective events. In this article, we use a radar merging technique similar to the ANTILOPE method from Météo France, with a higher resolution network. The tool employed is the Estimages toolbox merger, based on krigine with external drift (KED) which has been demonstrated to give good results in quantitative precipitation estimation (QPE) improvement.
\end{abstract}

\section{Introduction}

Champagne is famous for their sparkling wines but also for its particular weather conditions (Briche et al 2009, Beltrando \& Briche 2010, Briche 2011). This particular weather has a direct influence on Champagne wines (Gerbier \& Rémois 1977) and of course will directly condition the human practices on the vines.
Rainfall is a one of the most important meteorological variables in viticulture (Bois 2007, Van Leeuwen et al 2009, Pauthier 2017), especially in a region like Champagne where irrigation is prohibited. So far, the only fully reliable technique to capture rainfall was the use of rain gauges (Pauthier 2017). In the context of sustainable viticulture, the problem encountered by winegrowers and interprofessionnal offices was to have reliable localized rainfall information. To complete this goal, 42 automatic weather stations were implemented over the 34000 ha Champagne appellation. This network has been conceived to have the best spatial distribution with a final aim of data spatialization (Langellier et al 2016). Even with such a resolution network, data is not precise enough for a parcel scale vine training. Since 2016, the Comité Champagne also offers the possibility to calculate rainfall amounts directly derived from radar imaging at every point of the Champagne appellation. A QPE evaluation of the tool has been made and show some leaks especially during convective events.

To improve radar QPE, a common strategy is to merge radar and rain gauge data. This technique allows to have a complete spatial coverage with a radar image and some correct rainfall estimations with a rain gauge correction (Champeaux 2009). This strategy has been applied in Champagne. The current paper reports the techniques employed and the obtained results.

\section{Material and method}

The study was conducted over the Champagne appellation. Champagne appellation is particular because of its geographical configuration with two well separated vineyards. A northern part composed of the Marne and Aisne vineyards where the climate is oceanic with continental influences (Joly et al 2010). These influences are represented by moderately cold winters, warm summers and an annual precipitation averaging $650 \mathrm{~mm}$. The southern part is the Côte-des-Bars vineyards where the continental influence is stronger, with colder winters, warmer summers and a precipitation of around $750 \mathrm{~mm}$.

\section{Weather stations}

In order to capture meteorological data, a 42 Pulsonic $\AA$ weather stations network (Fig 1) is implemented in the Champagne appellation area. Rainfall is registered by $0.2 \mathrm{~mm}$ resolution Précis Mécanique $\AA$ rain gauges. These rain gauges are cleaned and calibrated every month in order to avoid any clogging or deviations. 
Comité Champagne weather station network

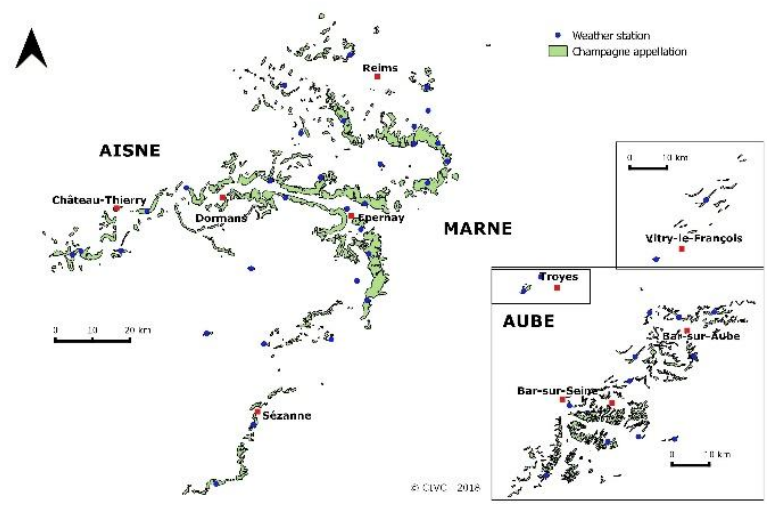

Fig 1. Comité Champagne weather station network (CCWN)

All data coming from the CCWN is validated and corrected every week by a method derived from the Météo France method.

\section{Radar data}

Since 2016, the Comité Champagne has an access to PANTHERE radar data from Météo France. This water blade is available at a $1 \mathrm{~km}^{2}$ resolution and $5 \mathrm{~min}$ time step (Tabary 2007). PANTHERE radar data is known for its tendency to underestimate rainfall amounts (Tabary 2007, Pauthier et al 2016, Pauthier 2017).

An evaluation made at daily time step over Champagne in early 2017 has shown better results than in these studies, but with the continued tendency of an underestimation that increases with the intensity of rainfall (Fig. 2).

\section{PANTHERE VS ObS}

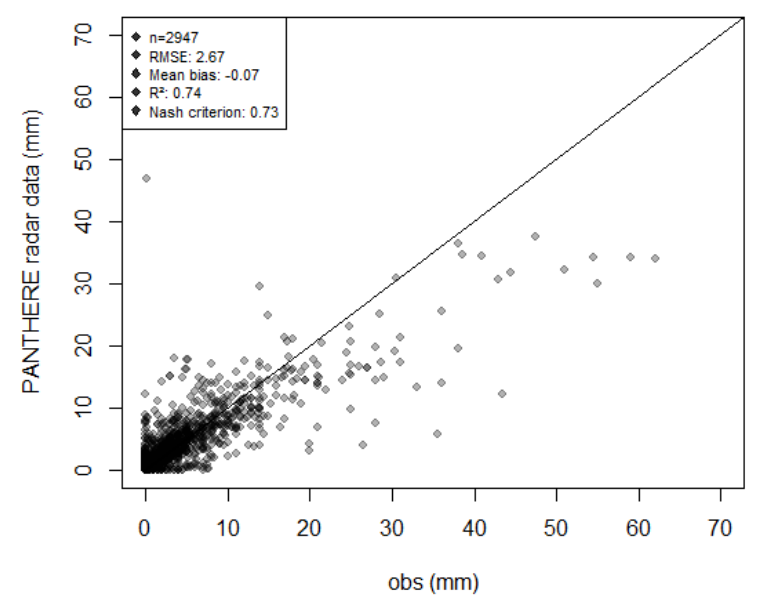

Fig 2. Results from the preliminary PANTHERE evaluation at daily time step in comparison to $\mathrm{CCWN}$ rain gauges
Considering these findings, the decision to find a technique to improve the QPE of PANTHERE data with CCWN data have been taken.

\section{Merging techniques}

Several methods allow to adjust radar estimations with rain gauges measurement such as the one used for the ANTILOPE radar product of Météo France. This method uses a krigged water blade coming from a rain gauge to adjust radar estimation only for stratiform events. When the events are convective, rain gauges are not used because of the low density of Météo France weather stations (MFWN Champeaux et al 2009, 2011). As this method considers only one type of event, we decided to use the Estimages ${ }^{\circledR}$ toolbox which uses cokriging with external drift (KED), giving good results in mountainous region (Sideris et al 2014). KED allows a modification of the model (radar) with a spatial coherency that fits observations while preserving the geographical structure. (Fig 3).

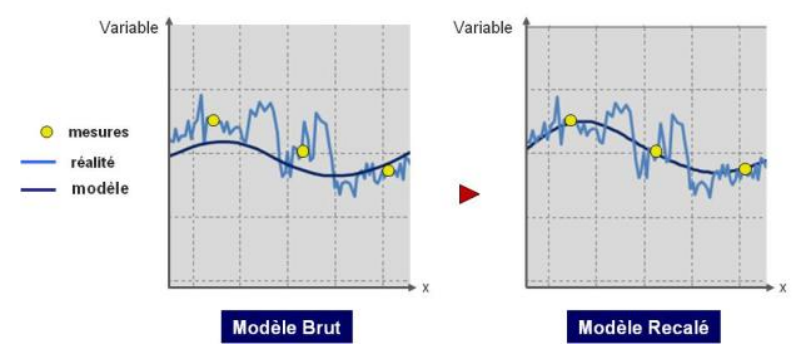

Fig 3. Left : model without correction by KED. Right : model with correction by KED

\section{Results}

To evaluate data coming from the merging of radar and CCWN data, totally independent Météo France rain gauges data were used. This data is coming from weather station located near or in Champagne vineyards in order to respect the merging area.

The stations of Reims, Troyes, Chouilly, and Celles-surOurce were therefore used to evaluate KED merged radar. A sample from the 2017 November $1^{\text {st }}$ to the 2018 April $15^{\text {th }}$ daily rainfall accumulation has been downloaded and compared to the merged radar data.

The obtained results show that the merger significantly increases the quality of the radar QPE. In fact, the statistics show a gain of almost $15 \%$ in the $\mathrm{R}^{2}$ and Nash criterion and a RMSE around 0,90 instead of 2,7 mm compared to the preliminary 2016 results (Fig 4) 


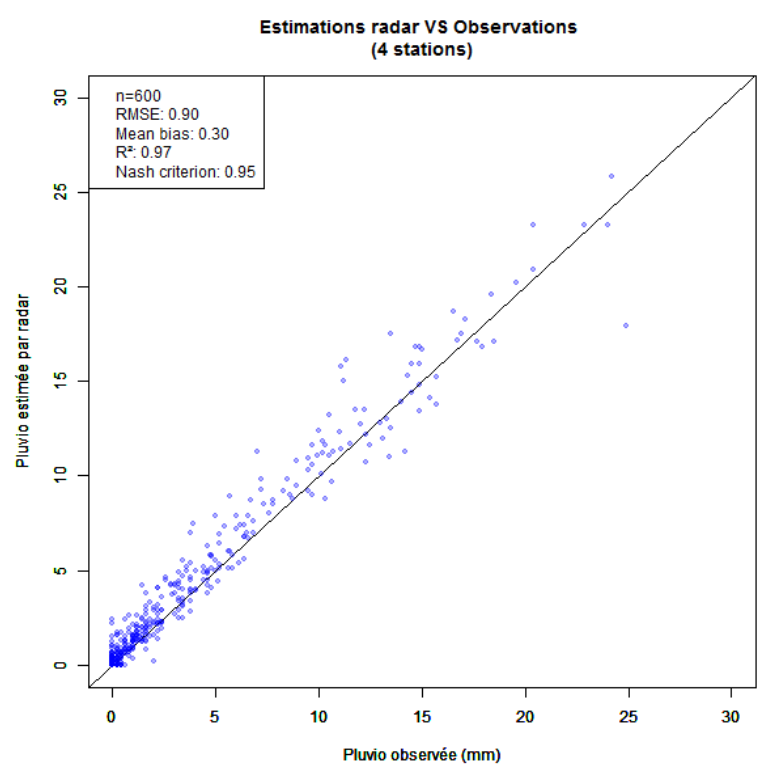

Fig 4. Results from the merged radar data evaluation at daily time step in comparison to 4 Météo France weather stations.

Considering the fact that two of these stations (Troyes and Chouilly) are used by Météo France to correct PANTHERE radar which is at the basis of the merger, we wanted to see if a difference of performance can be seen between the different stations. Individual plots (Fig. 5) has been made to compare the performance of the merger to each station and identify an eventual difference of performance depending on the considered station.
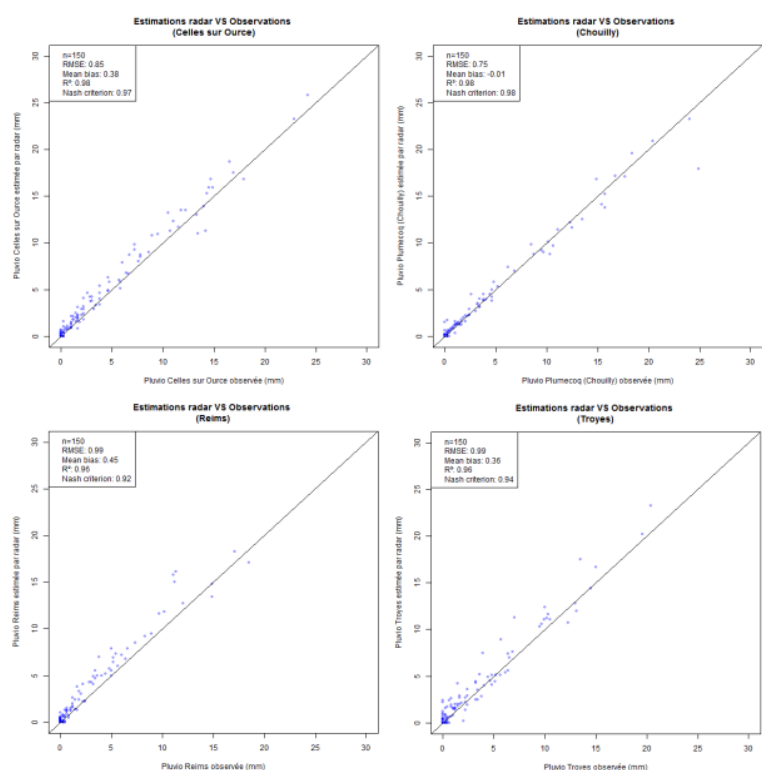

Fig 5. Results from the merged radar data evaluation at daily time step in comparison to 4 individual Météo France weather stations.

The two left plots illustrate the performance of Celles sur Ource and Reims stations which are not used in the PANTHERE algorithm, and the two on the right show the performance of Chouilly and Troyes which are used. No significant differences can be seen between used and non-used weather stations. A t-test confirmed the fact that there is no significant differences between the 4 stations.

\section{Conclusion and discussion}

Rainfall data is one of the most important weather parameters in viticulture. It is essential for precise vine management, especially in the context of sustainable viticulture. Until now, the only solution available for winegrowers wanting precise rainfall data was to have as many rain gauges as parcels.

Considering these results, the use of merged radar data to manage the vines at local scale can simplify the task of winegrowers. Nevertheless, these estimations do not replace the use of a rain gauge which still acts as a reference.

Moreover, considering the period of evaluation, from November 2017 to April 2018 only few convective or shower events have been taken into account. These conclusions can be therefore only made for stratiform events which present a low spatial variability.

Further studies are therefore needed to assess the performance of this method over a larger data sample.

BELTRANDO, Gérard et BRICHE, Elodie.

Changement climatique et viticulture en Champagne: du constat actuel aux prévisions du modèle ARPEGEClimat sur l'évolution des températures pour le XXIe siècle. EchoGéo, 2010, no 14.

BOIS, Benjamin. Cartographie agroclimatique à mésoéchelle: méthodologie et application à la variabilité spatiale du climat en Gironde viticole. Conséquences pour le développement de la vigne et la maturation $d u$ raisin. 2007. Thèse de doctorat. Université Sciences et Technologies-Bordeaux I.

BRICHE, Élodie. Changement climatique dans le vignoble de Champagne: modélisation thermique à plusieurs échelles spatio-temporelles. 2011. Thèse de doctorat. Paris 7.

BRICHE, Élodie, BELTRANDO, Gérard, CAUTENET, Sylvie, et al. Vagues de chaleur dans la région du vignoble du Champagne jusqu'en 2050 Heat waves in the Champagne wine region until 2050. CHAMPEAUX, Jean-Louis, DUPUY, Pascale, LAURANTIN, Olivier, et al. Les mesures de précipitations et l'estimation des lames d'eau à MétéoFrance: état de l'art et perspectives. La Houille Blanche, 2009, no 5, p. 28-34.

CHAMPEAUX, J. L., LAURANTIN, O., MERCIER, B., et al. Quantitative precipitation estimations using rain gauges and radar networks: inventory and prospects at Meteo-France. In : WMO joint meeting of CGS expert team on surface-based remotely-sensedobservations \& CIMO expert teamon operational remote sensing, Geneva. 2011. p. 5-9.

GERBIER, Norbert et RÉMOIS, Paul. Influence $d u$ climat sur la qualité et la production du vin de Champagne. Météorologie nationale, 1977. 
JOLY, Daniel, BROSSARD, Thierry, CARDOT, Hervé, et al. Les types de climats en France, une construction spatiale. Cybergeo: European Journal of Geography, 2010.

PAUTHIER, Basile, BOIS, Benjamin, CASTEL, Thierry, et al. Mesoscale and local scale evaluations of quantitative precipitation estimates by weather radar products during a heavy rainfall event. Advances in Meteorology, 2016, vol. 2016.

PAUTHIER, Basile. Etude de la variabilité spatiotemporelle des précipitations aux échelles fines: conséquences potentielles pour la viticulture en Bourgogne. 2017.

SIDERIS, I. V., GABELLA, M., ERDIN, R., et al. Real-time radar-rain-gauge merging using spatio-temporal co-kriging with external drift in the alpine terrain of Switzerland. Quarterly Journal of the Royal Meteorological Society, 2014, vol. 140, no 680, p. 1097-1111.

TABARY, P. The new French operational radar rainfall product. Part I: Methodology. Weather and forecasting, 2007, vol. 22, no 3, p. 393-408.

VAN LEEUWEN, Cornelis, TREGOAT, Olivier, CHONÉ, Xavier, et al. Vine water status is a key factor in grape ripening and vintage quality for red Bordeaux wine. How can it be assessed for vineyard management purposes. J. Int. Sci. Vigne Vin, 2009, vol. 43, no 3, p. 121-134. 